\title{
Autophagy Facilitates the Sorafenib Resistance of Hepatocellular Carcinoma Cells
}

\author{
B Liu, Y Cao, H Jiang, A Mao
}

\begin{abstract}
Liver cancer is the second most frequent cause of cancer death in men and the sixth leading cause of cancer death in women. Hepatocellular carcinoma (HCC) represents the major subtype in liver cancer and its five-year survival rate remains very poor. Sorafenib, a molecular targeted therapeutic agent, was the first drug approved for the treatment of patients with HCC. However, the clinical response of sorafenib was seriously limited by drug resistance. Autophagy is an evolutionarily conserved mechanism among all eukaryotes. Recently, many studies have indicated that autophagy can be activated as a cellular protective mechanism in many tumour cells. Thus, we hypothesized that autophagy may play an important role in resistance to sorafenib in hepatocellular carcinoma. Although the exact role of autophagy in the sorafenib resistance of HCC is still complex and further studies are needed to be proven, at least it suggests that autophagy may be a new therapeutic target for the sorafenib resistance of $\mathrm{HCC}$.
\end{abstract}

Keywords: Autophagy, chemo-resistance, hepatocellular carcinoma

\section{La Autofagia Facilita la Resistencia al Sorafenib de las Células del Carcinoma Hepatocelular}

\author{
B Liu, Y Cao, H Jiang, A Mao
}

\begin{abstract}
RESUMEN
El cáncer de hígado es la segunda causa de muerte más frecuente por cáncer en los hombres y la sexta causa de muerte por cáncer en las mujeres. El carcinoma hepatocelular (CHC) representa el subtipo principal en el cáncer de hígado, y su tasa de supervivencia de cinco años sigue siendo muy pobre. El sorafenib, un agente terapéutico dirigido selectivamente a moléculas especificas, fue el primer medicamento aprobado para el tratamiento de pacientes con CHC. Sin embargo, la respuesta clínica de sorafenib estaba seriamente limitada por la resistencia al medicamento. La autofagia es un mecanismo evolutivamente conservado entre todos las eucariotas. Recientemente, muchos estudios han indicado que la autofagia puede activarse como mecanismo de protección celular en muchas células tumorales. Por consiguiente, postulamos la hipótesis de que la autofagia puede desempeñar un papel importante en la resistencia del carcinoma hepatocelular al sorafenib. Aunque el papel exacto de la autofagia en la resistencia al sorafenib del CHC es aún complejo y se necesitan estudios adicionales para ser probado, al menos se sugiere que la autofagia puede ser una nueva meta terapéutica frente a la resistencia del sorafenib en el CHC.
\end{abstract}

Palabras claves: autofagia, quimiorresistencia, carcinoma hepatocelular

West Indian Med J 2013; 62 (8): 698

From: Department of Interventional Radiology, St Luke's Hospital, Shanghai 200050, PR China.

Correspondence: Dr A Mao, Department of Interventional Radiology, St Luke's Hospital, 786 Yuyuan Road, Shanghai 200050, PR China. E-mail: maoaw@sohu.com

\section{INTRODUCTION}

Liver cancer is the second most frequent cause of cancer death in men and the sixth leading cause of cancer death in women (1). Among the primary liver cancers, hepatocellular carcinoma (HCC) represents the major subtype (2). Presently, although many different treatments including surgery 
and chemotherapy have been widely used, the therapeutic effect on the patients with HCC is still limited (3). Therefore, it is very important and critical to find new agents with better efficacy and safety in the treatment of patients with HCC.

Recently, molecular targeted therapies have created an encouraging trend in the management of HCC (4). Sorafenib, a molecular targeted therapeutic agent, was the first drug approved for the treatment of patients with unresectable HCC by the Food and Drug Administration of the United States of America [USA] (5). Sorafenib, acting as a multikinase inhibitor, combines two anticancer activities: blocks tumour cell proliferation by targeting Raf/MAPK-ERK kinase (MEK)/extracellular signalling-regulated kinase (ERK) signalling and inhibits tumour angiogenesis by targeting VEGFRs and PDGFR tyrosine kinases, since kinases play key roles in tumour cell proliferation, apoptosis and tumour angiogenesis (6-8). However, development of resistance and limited efficacy of sorafenib in patients with advanced HCC are deficiencies of the therapy (9). Thus, it is very important to explore the detailed mechanisms underlying the resistance to this compound to help improve the therapeutic effect of HCC.

Macroautophagy (hereafter referred to as autophagy) is an evolutionarily conserved mechanism by which cytoplasm and organelles are digested via autophagosomes and autolysosomes and cellular components are recycled for energy utilization (10). In addition to its homeostatic role, the autophagic process allows cells to survive nutrient stress, by providing amino acids and fatty acids to maintain metabolic levels. So autophagy may be regarded as a probable mechanism for drug resistance. For example, inhibition of autophagy can enhance the effects of apoptosis induced by cisplatin in oesophageal cancer cells (11).

The Raf-MAK-ERK pathway, as one of the targets of sorafenib, is one of the molecular regulation mechanisms of autophagy (12), which indicates an underlying association between sorafenib and the regulation of autophagy. Moreover, a previous study has proven that inhibition of autophagy can potentiate the antitumour effect of the multikinase inhibitor sorafenib in HCC (13). Thus, we speculate that autophagy inhibition may be a novel way of increasing the efficiency of sorafenib in the treatment of HCC.

\section{Background and evidence}

Although autophagy can be activated by different anticancer drugs in many different cancer cell lines including HCC cells (14), the exact role of autophagy in tumour cell death or survival is still unclear. Autophagy can be up-regulated to promote cell survival through the degradation of cellular proteins and organelles when facing cellular stress, and can be regarded as a mechanism which can promote the growth of established tumours (15). Thus, it could serve as a potent oncogenic mechanism to promote tumour cell survival.
In fact, many studies have indicated that induction of autophagy can enhance tumour resistance to different anticancer therapies in different tumour cell lines (16). In breast cancer cells, Aurora kinase A inhibition-induced autophagy can trigger drug resistance, which may represent a novel mechanism of drug resistance in apoptosis-aimed therapy for breast cancer (17). In oesophageal cancer cell, autophagy can promote these drug-resistant cancer cell survival and recovery following treatment with chemotherapeutics (18). In addition, autophagy may function importantly in HepG2 cell resistance to oxaliplatin and the resistance could be recovered apparently by inhibition of autophagy (19). Therefore, these results have indicated that autophagy may play an important role in the mechanism of the tumour cells resistant to anti-cancer drugs.

Other studies have proven that autophagy can protect tumour cells against the effect of sorafenib. In the HCC cells, autophagy can be activated by sorafenib and inhibition of autophagy by chloroquine and siRNA can augment the growth inhibitory effect of sorafenib, which suggests that the combination of autophagy modulation and molecular targeted therapy is a promising therapeutic strategy in treatment of HCC (20). Moreover, other reports have also noted that sorafenib can stimulate autophagy through inhibition of class III RTKs, and that in a dose-dependent effect this response can either be a protective form of autophagy or a toxic form of autophagy $(21,22)$. These findings suggest that inhibition of autophagy induced by sorafenib can improve treatment efficacy. Thus, in combination with therapeutic strategies that aim to inhibit autophagy in patients treated with conventional chemotherapy, novel targeted therapy with sorafenib represents a promising approach with higher efficacy for patients with HCC.

Previous studies have suggested that inhibition of autophagy can enhance the efficacy of sorafenib in HCC cells (20-22). Therefore, we present that autophagy may facilitate the sorafenib resistance of HCC cells, which might be one of the mechanisms of tumour recurrence and metastasis.

\section{CONCLUSION}

In recent years, the role of autophagy in the chemoradiotherapy resistance of cancer cells has been investigated extensively. Although the function of autophagy in sorafenib resistance is still uncertain and more studies are needed to explore the possible resistance mechanism, at least it offers a new potential strategy for overcoming resistance to sorafenib.

\section{REFERENCES}

1. Jemal A, Bray F, Center MM, Ferlay J, Ward E, Forman D. Global cancer statistics. CA Cancer J Clin 2011; 61: 69-90.

2. El-Serag HB. Hepatocellular carcinoma. N Engl J Med 2011; 365: 1118-27.

3. Llovet JM, Burroughs A, Bruix J. Hepatocellular carcinoma. Lancet 2003; 362: 1907-17. 
4. Llovet JM, Bruix J. Molecular targeted therapies in hepatocellular carcinoma. Hepatology 2008; 48: 1312-27.

5. Kane RC, Farrell AT, Madabushi R, Booth B, Chattopadhyay S, Sridhara R et al. Sorafenib for the treatment of unresectable hepatocellular carcinoma. Oncologist 2009; 14: 95-100.

6. Wilhelm SM, Carter C, Tang L, Wilkie D, McNabola A, Rong H et al. BAY 43-9006 exhibits broad spectrum oral antitumor activity and targets the RAF/MEK/ERK pathway and receptor tyrosine kinases involved in tumor progression and angiogenesis. Cancer Res 2004; 64: 7099-109.

7. Wilhelm S, Carter C, Lynch M, Lowinger T, Dumas J, Smith RA et al. Discovery and development of sorafenib: a multikinase inhibitor for treating cancer. Nat Rev Drug Discov 2006; 5: 835-44.

8. Gauthier A, Ho M. Role of sorafenib in the treatment of advanced hepatocellular carcinoma: an update. Hepatol Res 2013; 43: 147-54. doi: 10.1111/j.1872-034X.2012.01113.x. Epub 2012 Nov 12.

9. Llovet JM, Ricci S, Mazzaferro V, Hilgard P, Gane E. Sorafenib in advanced hepatocellular carcinoma. N Engl J Med 2008; 359: 378-90.

10. Chen N, Karantza V. Autophagy as a therapeutic target in cancer. Cancer Biol Ther 2011; 11: 157-68.

11. Liu D, Yang Y, Liu Q, Wang J. Inhibition of autophagy by 3-MA potentiates cisplatin-induced apoptosis in esophageal squamous cell carcinoma cells. Med Oncol 2011; 28: 105-11.

12. Yang Z, Klionsky DJ. Eaten alive: a history of macroautophagy. Nat Cell Biol 2010; 12: 814-22.

13. Shimizu S, Takehara T, Hikita H, Kodama T, Tsunematsu H, Miyagi T et al. Inhibition of autophagy potentiates the antitumor effect of the multikinase inhibitor sorafenib in hepatocellular carcinoma. Int $\mathrm{J}$ Cancer 2012; 131: 548-57.

14. Janku F, McConkey DJ, Hong DS, Kurzrock R. Autophagy as a target for anticancer therapy. Nat Rev Clin Oncol 2011; 8: 528-39.
15. Carew JS, Kelly KR, Nawrocki ST. Autophagy as a target for cancer therapy: new developments. Cancer Manag Res 2012; 4: 357-65.

16. Chen LH, Loong CC, Su TL, Lee YJ, Chu PM, Tsai ML et al. Autophagy inhibition enhances apoptosis triggered by BO-1051, an Nmustard derivative, and involves the ATM signaling pathway. Biochem Pharmacol 2011; 81: 594-605.

17. Zou Z, Yuan Z, Zhang Q, Long Z, Chen J, Tang Z et al. Aurora kinase A inhibition-induced autophagy triggers drug resistance in breast cancer cells. Autophagy 2012; 8: 1798-10.

18. O'Donovan TR, O'Sullivan GC, McKenna SL. Induction of autophagy by drug-resistant esophageal cancer cells promotes their survival and recovery following treatment with chemotherapeutics. Autophagy 2011; 7: 509-24.

19. Du H, Yang W, Chen L, Shi M, Seewoo V, Wang J et al. Role of autophagy in resistance to oxaliplatin in hepatocellular carcinoma cells. Oncol Rep 2012; 27: 143-50. DOI: 10.3892/or.2011.1464. Epub 2011 Sep 20.

20. Shi YH, Ding ZB, Zhou J, Hui B, Shi GM, Ke AW et al. Targeting autophagy enhances sorafenib lethality for hepatocellular carcinoma via ER stress-related apoptosis. Autophagy 2011; 7: 1159-72.

21. Park MA, Reinehr R, Häussinger D, Voelkel-Johnson C, Ogretmen B, Yacoub A et al. Sorafenib activates CD95 and promotes autophagy and cell death via Src family kinases in gastrointestinal tumor cells. Mol Cancer Ther 2010; 9: 2220-31.

22. Martin AP, Park MA, Mitchell C, Walker T, Rahmani M, Thorburn A et al. BCL-2 family inhibitors enhance histone deacetylase inhibitor and sorafenib lethality via autophagy and overcome blockade of the extrinsic pathway to facilitate killing. Mol Pharmacol 2009; 76: $327-41$. 